\title{
Bahaya Merokok Bagi Masa Depan dan Kesehatan
}

\author{
Muhammad Ibnu Aksol M, Muhammad Ali Sodik \\ IIK Strada Indonesia \\ akslibnu@gmail.com, alisodik2012@gmail.com
}

\begin{abstract}
Abstrak
Merokok merupakan sebuah aktivitas yang kini banyak di gemari oleh para remaja pada masa sekarang ini. Dahulu kala merokok hanyalah menjadi bagian dari kehidupan orang -orang tua. Tapi kini merokok sudah merambah ke dalam kehidupan anak-anak sekolah mulai dari SMA-SMP dan yang paling parahnya lagi sudah ada sebagian anak SD yang sudah pandai Merokok. Orang-orang yang menjadi perokok aktif mengatakan bahwa merokok itu mengasyikkan dan menyenangkan karena dapat menghilangkan stress. Tetapi dibalik kenikmatan yang dirasakan oleh para perokok tersebut terdapat bahaya yang sangat mematikan bagi dirinya dan kehidupan masa depannya. Apabila Merokok telah menjadi sebuah kebiasaan yang dilakukan oleh masyarakat pada umumnya, maka bahaya merokok juga akan mengintai masa depan dan juga kesehatannya.Penyakit yang timbul akan tergantung dari kadar zat berbahaya yang terkandung, kurun waktu kebiasaan merokok, dan cara menghisap rokok. Semakin muda seseorang mulai merokok, makin besar risiko orang tersebut mendapat penyakit saat tua.
\end{abstract}

Kata kunci : Merokok, masa depan, kesehatan.

\section{1. latar belakang}

Sekarang ini merokok sudah menjadi kebiasaan yang sangat umum dan meluas di masyarakat. Bahaya merokok terhadap kesehatan tubuh telah dirasakan banyak orang dan efek-efek yang ditimbulkan pun sudah diketahui dengan jelas. Banyak penelitian membuktikan kebiasaan merokok menyebabkan timbulnya berbagai penyakit dalam tubuh kita, seperti penyakit jantung dan gangguan pembuluh darah, kanker paruparu, kanker rongga mulut, kanker laring, tekanan darah tinggi, impotensi serta gangguan kehamilan dan cacat pada janin. Bahaya rokok juga bukan hanya ditunjukkan bagi para perokok (perokok aktif) tetapi juga bagi orang-orang yang bukan perokok menghirup asap rokok yang berada disekitar perokok (perokok Pasif) dan justru efek yang di terima dari perokok pasif akan jauh lebih berbahaya dari perokok aktif. Rokok salah satu penyebab kematian utama di dunia dan merupakan satusatunya produk legal yang membunuh hingga setengah penggunaannya. Kebiasaan merokok sedikitnya menyebabkan 30 jenis penyakit 
pada manusia, pada

kenyataannya kebiasaan

merokok ini sulit dihilangkan

dan jarang diakui orang sebagai

suatu kebiasaan buruk. Apalagi

orang yang merokok untuk

\section{Kasus masalah}

Perilaku merokok pada anak usia sekolah merupakan masalah sosial yang sampai saat ini belum bisa diatasi dan mengalami peningkatan di setiap tahunnya. Perilaku merokok pada remaja SMK Daerah Situbondo dimulai sejak anak berusia dini. Hal ini tentu sangat menghawatirkan melihat kondisi anak yang memilih merokok di usianya yang sangat muda. Semakin anak mengkonsumsi rokok sejak usia dini akan semakin menambah angka kematian karena rokok yang mengandung nikotin.

Selain itu, anak yang mengkonsumsi rokok sejak usia dini akan mengalami derajat ketergantungan pada rokok semakin tinggi dan mengalami dampak gangguan kesehatan. Perilaku merokok pada anak usia sekolah di SMK Daerah Situbondo dimulai sejak anak menempuh pendidikan Sekolah Dasar. Hal ini disebabkan karena kurangnya pengetahuan tentang bahaya merokok dan

\section{Tinjauan pustaka}

Perilaku merokok adalah suatu aktivitas menghisap asap tembakau yang dibakar ke dalam tubuh dan menghembuskannya mengalihkan diri dari stress dan tekanan emosi, lebih sulit melepaskan kebiasaan ini dibandingkan perokok yang tidak memiliki latar belakang depresi.

lemahnya kesadaran masyarakat yang mengkonsumsi rokok di depan anak berusia dini. Akibatnya seorang anak melihat, kemudian mengidentifikasi tentang rokok hingga timbul rasa ingin tahu pada rokok. Makna merokok bagi seorang remaja yaitu rokok sebagai kebiasaan hidup yaitu remaja yang mengkonsumsi rokok akan mengalami ketergantungan pada rokok karena kandungan nikotin yang ada dalam rokok. Akibatnya remaja yang terbiasa merokok akan merasa kebingungan ketika rokok yang dikonsumsinya telah habis. Remaja merasa membutuhkan rokok untuk meningkatkan semangat dalam beraktivitas. Kemudian rokok sebagai jati diri dan persepsi tentang kejantanan bahwa melalui rokok seorang remaja merasa percaya diri dengan identitasya sebagai seorang laki-laki. Perilaku merokok pada anak usia sekolah juga diperkuat oleh keluarga yakni pihak keluarga yang mengizinkan seorang remaja merokok

kembali keluar (Amstrong, 1990). Menurut Sitepoe (2000) perilaku merokok didefinisikan sebagai aktivitas membakar tembakau 
yang kemudian dihisap asapnya, baik langsung menggunakan rokok maupun menggunakan pipa. Asap yang dihisap melalui mulut disebut mainstream smoke, sedangkan asap rokok yang terbentuk pada ujung rokok yang terbakar serta asap rokok yang dihembuskan ke

\section{a. Faktor Psikologis}

Merokok dapat menjadi sebuah cara bagi individu untuk santai dan kesenangan, tekanan-tekanan teman sebaya, penampilan diri, sifat ingin tahu, stres, kebosanan dan ingin kelihatan gagah merupakan hal-hal yang dapat mengkontribusi mulainya merokok. Selain itu, individu dengan gangguan cemas bisa menggunakan rokok untuk menghilangkan kecemasan yang mereka alami. Menurut Yoder \& Staudohar (1982) stres antara lain permasalahan yang terjadi ditempat kerja, stres tersebut digolongkan sebagai stres kerja. Menurut Anwar (1990) stres kerja adalah suatu perasaan yang menekan atau rasa tertekan yang dialami karyawan dalam menghadapi pekerjaannya.

\section{b. Faktor Biologis}

faktor genetik dapat dapat mempengaruhi seseorang untuk mempunyai ketergantungan terhadap rokok. faktor lain yang mungkin mengkontribusi perkembangan kecanduan nikotin adalah merasakan adanya efek bermanfaat dari nikotin. Proses biologinya yaitu nikotin diterima reseptor asetilkotin-nikotinik yang kemudian membagi ke jalur imbalan dan jalur adrenergenik. udara oleh perokok disebut sidestream smoke. Sidestream smoke atau asap sidestream mengakibatkan seseorang menjadi perokok pasif.

\section{Faktor yang mempengaruhi} seseorang merokok:

Pada jalur imbalan, perokok akan merasakan nikmat, memacu sistem dopaminergik. Hasilnya perokok akan merasa lebih tenang, daya pikir serasa lebih cemerlang, dan mampu menekan rasa lapar. Di jalur adrenergik, zat ini akan mengaktifkan sistem adrenergik pada bagian otak lokus seruleus yang mengeluarkan sorotin. Meningkatnya sorotin menimbulkan rangsangan rasa senang sekaligus keinginan mencari rokok lagi. Hal inilah yang menyebabkan perokok sangat sulit meninggalkan rokok, karena sudah ketergantungan pada nikotin. Ketika ia berhenti merokok rasa nikmat yang diperolehnya akan berkurang.

\section{c. Faktor Lingkungan}

Faktor lingkungan berkaitan dengan penggunaan tembakau antara lain orang tua, saudara kandung maupun teman sebaya yang merokok, reklame tembakau, artis pada reklame tembakau di media. Orang tua memegang peranan terpenting, selain itu juga reklame tembakau 16 diperkirakan mempunyai pengaruh yang lebih kuat daripada pengaruh orang tua atau teman sebaya, hal ini mungkin karena me mpengaruhi persepsi remaja terhadap penampilan dan manfaat rokok. 


\section{Pembahasan}

Rokok adalah lintingan atau gulungan tembakau yang digulung / dibungkus dengan kertas, daun, atau kulit jagung, sebesar kelingking dengan panjang 8-10 cm, biasanya dihisap seseorang setelah dibakar ujungnya. Rokok merupakan pabrik bahan kimia berbahaya. Hanya dengan membakar dan menghisap sebatang rokok saja, dapat diproduksi lebih dari 4000 jenis bahan kimia. 400 diantaranya beracun dan 40 diantaranya bisa berakumulasi dalam tubuh dan dapat menyebabkan kanker. Rokok juga termasuk zat adiktif karena dapat menyebabkan adiksi (ketagihan) dan dependensi (ketergantungan) bagi orang yang menghisapnya. Dengan kata lain, rokok termasuk golongan NAPZA (Narkotika, Psikotropika, Alkohol, dan Zat Adiktif).

\section{Berbagai Gangguan Kesehatan}

Akibat Merokok :

Kandungan zat kimia yang

terdapat dalam rokok sangat berbahaya bagi kesehatan Anda dan juga orang-orang di sekitar Anda. Bahaya merokok bagi kesehatan di antaranya yaitu:

- Otak

Bahaya merokok bisa meningkatkan risiko terkena stroke sebesar 50 persen. Hal tersebut bisa menyebabkan kerusakan otak dan kematian. Merokok juga dapat meningkatkan risiko mengalami aneurisma otak . Aneurisma otak adalah pembengkakan pembuluh darah yang terjadi akibat melemahnya dinding pembuluh darah.

- Mulut dan tenggorokan Bau mulut dan gigi bernoda (hitam atau kuning) merupakan efek yang akan timbul akibat merokok. Masalah serius yang akan hinggap pada mulut dan tenggorokan adalah meningkatnya risiko kanker pada lidah, tenggorokan, bibir, dan pita suara.

- Paru-paru

Salah satu efek paling berbahaya akibat merokok adalah kanker paru-paru. Bahan-bahan kimia pada rokok berpotensi merusak sel paru-paru yang kemudian bisa berubah menjadi sel kanker. Merokok juga merupakan salah satu faktor penyebab TBC.

- Lambung

Merokok bisa melemahkan otot yang mengontrol bagian bawah kerongkongan Anda. Hal tersebut memungkinkan asam dari lambung bergerak ke arah yang salah, yaitu naik ke kerongkongan. Kondisi tersebut dinamakan penyakit asam lambung atau GERD. 
- Kulit

Perokok akan terlihat lebih tua

daripada yang bukan perokok, karena kurangnya asupan oksigen

ke kulit.

- Organ reproduksi

Pada pria, merokok bisa

menyebabkan impotensi,

mengurangi produksi sperma, dan

kanker testis. Sementara pada

\section{Kesimpulan}

Hampir seluruh warga negara Indonesia baik itu dewasa, orang tua, dan remaja membudayakan merokok sebagai penunjang aktivitas atau kebiasaan, sedangkan merokok memiliki dampak yang sangat banyak terhadap berbagai macam penyakit yang dapat menyerang orang yang merokok itu maupun

\section{Daftar pustaka}

Sodik, M. A. (2018). Merokok \&

Bahayanya.

Setyani, A. T., \& Sodik, M. A. (2018).

Pengaruh Merokok Bagi Remaja

Terhadap Perilaku dan Pergaulan

Sehari-hari.

Sodik, M. A., \& Setyani, A. T. (2018).

Effect of Smoking For Teens Against

Behavior and Social Interaction.

Sodik, M. A., Astikasari, N. D., Fazrin,

I., Chusnatayaini, A., \& Peristiowati, Y.

(2018). Dental health child with retardation mental and parents behavior. Indian Journal of Physiotherapy and Occupational Therapy-An International

Journal, 12(4), 278-282.

Sodik, M. A., \& Nzilibili, S. M. M. (2017). The Role Of Health Promotion And Family Support With Attitude Of Couples Childbearing Age In

Following Family Planning Program In wanita, merokok dapat mengurangi kesuburan.

- Gangguan psikologis

Selain penyakit pada fisik, perokok juga mengalami tingkat stres yang lebih tinggi dibandingkan mereka yang tidak merokok. Kandungan nikotin yang membuat perokok gelisah dan cemas adalah gejala putus obat terhadap nikotin.

orang yang tidak merokok. Penyakit-penyakit ini juga dapat berdampak pada kematian. Dorongan untuk berhenti merokok pada remaja berasal dari diri sendiri dan dorongan dari keluarga atau orang lain. Berhenti merokok merupakan cara terbaik menghindari dan mengurangi dampak buruk akibat asap rokok dan penyakit akibat merokok.

Health. Journal of Global Research in Public Health, 2(2), 82-89.

"bahaya merokok" diunduh dari (http://notewhy.blogspot.com/2012/09/artikeltentang-bahaya-merokok.html) "bahaya merokok bagi remaja" diundah dari (http://nuridha.blogspot.com/2011/0 1/bahaya-merokok-bagiremaja 19.html)

Manusia Bahaya Merokok Bagi Tubuh". hal. 3. Hurlock, E.B (1998). Perkembangan Anak. Alih bahasa oleh Soedjarmo \& Istiwidayanti. Jakarta: Erlangga 